\title{
Community pharmacist home visit-based intervention improved diabetes patients' outcomes: A randomized controlled trial
}

\author{
Tunggul Adi Purwonugroho ${ }^{1 *}$, Budi Raharjo ${ }^{1,2}$, Laksmi Maharani ${ }^{1}$, Ika Mustikaningtias ${ }^{1}$, Vitis Vini Fera Ratna Utami ${ }^{1}$, Githa \\ Fungi Galistiani ${ }^{2}$, Hanif Nasiatul Baroroh ${ }^{1}$, Hening Pratiwi ${ }^{1}$, Pugud Samodro ${ }^{3}$, Jamaludin Al J. Efendi ${ }^{4}$, Didik Setiawan ${ }^{2}$ \\ ${ }^{1}$ Department of Pharmacy, Faculty of Health Sciences, University of Jenderal Soedirman, Purwokerto, Indonesia \\ ${ }^{2}$ Faculty of Pharmacy, University of Muhammadiyah Purwokerto, Purwokerto, Indonesia \\ ${ }^{3}$ Faculty of Medicine, University of Jenderal Soedirman, Purwokerto, Indonesia \\ ${ }^{4}$ Faculty of Pharmacy, University of Pekalongan, Pekalongan, Indonesia
}

\begin{tabular}{l}
\hline ARTICLE INFO \\
\hline Received on: 08/10/2020 \\
Accepted on: 19/01/2021 \\
Available online: 05/03/2021 \\
\hline Key words: \\
Community pharmacist, \\
diabetes, Indonesia, \\
randomized controlled trial.
\end{tabular}

\section{INTRODUCTION}

Diabetes is a chronic disease with long-term complication which contributes to the development of cardiovascular disease, retinopathy, nephropathy, neuropathy, and a higher risk of cancer (Harding et al., 2019; Papatheodorou et al., 2018). Currently, this major health issue has reached an unprecedented level, with just under half a billion people living with this condition globally (Saeedi et al., 2019), and it is predicted to contribute to $11.3 \%$ of death among 20-79-year-old adults worldwide (Saeedi

\footnotetext{
*Corresponding Author

Tunggul Adi Purwonugroho, Department of Pharmacy, Faculty of Health Sciences, University of Jenderal Soedirman, Purwokerto, Indonesia. E-mail:tunggul.adi@gmail.com
}

et al., 2020). Indonesia, the fourth most populous country, has approximately 10.7 million adults with diabetes (Saeedi et al., 2019) and put this condition among the highest economic burden for noncommunicable disease in the country (Agustina et al., 2019; Finkelstein et al., 2014). We focused on type 2 diabetes since 97.5 percent of people with diabetes in Indonesia have this type of disease (Soewondo et al., 2010). The term "diabetes" in this article therefore refers to type 2 diabetes.

To achieve the desired blood glucose level, patients must adhere to their healthy diet and exercise, self-monitoring of blood glucose, and appropriate use of medication (Ahola and Groop, 2013; Inzucchi et al., 2012). Collaboration with healthcare providers could reinforce diabetes patients to self-manage their condition. Plenty of evidence reported that pharmacists, as one of the frontline healthcare providers, significantly improved diabetic patients' outcomes (clinical, humanistic, and economic) 
by assisting their self-management activities (Bukhsh et al., 2018; Yaghoubi et al., 2017). Pharmacists delivered their support through a home visit or in the healthcare setting. There were several types of pharmacist intervention, such as education about diabetes and its complications; medication adherence counseling; supplying written educational material, free glucose meter, and pill counter; information on lifestyle modification; and self-monitoring blood glucose education (Bukhsh et al., 2018; Yaghoubi et al., 2017).

With the fact that Indonesia is positioned as the seventh country in the world which has the largest number of people living with diabetes (Saeedi et al., 2019) and there are a sufficient number of community pharmacists in the country, robust research to validate the benefit of community pharmacist on diabetes care is in demand. This study aimed to evaluate the effectiveness of home visit intervention by community pharmacists in managing diabetes patients for a $24-w e e k$ period. The outcomes measured were $\mathrm{HbAlc}$ and quality of life.

\section{MATERIALS AND METHODS}

\section{Participants}

This 24-week randomized controlled parallel-group trial was conducted in Banyumas district, Central Java province, Indonesia. The participating pharmacists were all pharmacists in Banyumas district who were working in a community pharmacy and willing to get involved in the project. To standardize the participating pharmacists, the International Diabetes Federation 2011 education modules (International Diabetes Federation, 2011) were translated into Indonesian language and used as the main source for 16-hour in-house training. The topics included diagnosis, classification, and diabetes prevention; pharmacology of antidiabetes; clinical monitoring; physical activity; hypoglycemia; and self-management education.

Meanwhile, the patient populations of this research were diabetes patients in Banyumas region who undertook "Prolanis" program ("program pengelolaan penyakit kronis"/management of chronic disease program) managed by Indonesian Health Insurance. Inclusion criteria of patients were as follows: diagnosed with type 2 diabetes, managed by community pharmacists who participated in this research, aged 45-65 years, using oral antidiabetic agents, and consent for being respondent. Patients using insulin therapy, having a relationship with community pharmacist/s who participated in this study, working as healthcare workers, and undergoing regular dialysis were excluded from this study.

The participating patients were obtained from the population using a purposive sampling technique. The researcher asked for patients' consent at the time of Prolanis program scheduled at their primary healthcare facilities. Patients who were having informed and gave their consent were recruited. The required sample size was determined based on the ability to detect the difference of $1 \%$ reduction of $\mathrm{HbAlc}$ with $1.2 \%$ standard deviation ( Regarding a previous study, 30 patients were needed under these circumstances (Kelly and Rodgers, 2000). Assuming a dropout rate of $20 \%, 6$ patients were added to each group with at least 36 patients for every arm. Subjects then were randomly allocated to the intervention and control group using an Internet-generated random sequence.

\section{Interventions}

Patients in the intervention group received home visits by participating pharmacists over the study period, while the control group only received usual care by pharmacists (drug dispensing and standard counseling in their primary healthcare facilities). The intervention provided in home visits was education about diabetes and its complications, how to use antidiabetic drugs properly, and healthy lifestyle management. Home visit was performed five times within the study period by week 0 , week 2 , week 6 , week 18 , and week 24 according to a former research study conducted in Belgium (Mehuys et al., 2011). Before the first visit, preintervention data (demographic data, HbA1c, and Diabetes Quality of Life Clinical Trial Questionnaire (DQLCTQ)] were collected. On the first visit, the pharmacist provided the education materials as mentioned above. Meanwhile, assessing potential drug-related problem was performed on the next four visits. Customized education was accordingly implemented based on each patient's problem. Finally, postintervention data (HbAlc level and DQLCTQ) were gathered after the fifth visit.

$\mathrm{HbA} 1 \mathrm{c}$ and quality of life as the study outcome along with the patients' demographic data (gender, age, duration of diabetes, and medication prescribed) were collected. $\mathrm{HbA} 1 \mathrm{c}$ was measured in the Clinical Laboratory of Orthopedic Hospital Purwokerto. Quality of life was assessed using the Diabetes Quality of Life Clinical Trial Questionnaire (DQLCTQ) (Shen et al., 1999) Indonesian version which has been previously validated by Hartati (2003).

\section{Analysis and ethical consideration}

Statistical analyses were performed using Statistical Package for the Social Sciences (SPSS) version 20.0 (SPSS Inc., IBM, Armonk, NY). The data were tested for normality before other statistical tests were taken, and parametric or nonparametric tests were carried out accordingly. The level of significance used in all tests was 0.05 (two-tailed).

Ethical clearance for this study was granted by the Medical and Health Research Ethics Committee of the Faculty of Medicine, Gadjah Mada University-Dr. Sardjito General Hospital number KE/FK/773/EC/2015, and the study was conducted following the Helsinki Declaration. The participating pharmacists and patients received a verbal and written explanation about the study as well as their right whether to participate or withdraw from the trial at any time. Written informed consent has been provided by all participants. Data were confidentially handled and only the research team had access to it.

\section{RESULTS}

This study was performed from December 2015 to July 2016 with 28 community pharmacists involved as participating pharmacists. Every visit, pharmacists spent around 30 minutes to provide educational materials to their patients. Figure 1 shows patient arrangement throughout the study. In the beginning, 46 and 49 patients who met the inclusion criteria and provided written consent were randomly assigned to the control group and intervention group, respectively. Almost all patients completed the study (control group: 41 out of 46 and intervention group: 47 out of 49). Reasons for withdrawal were as follows: died (three 


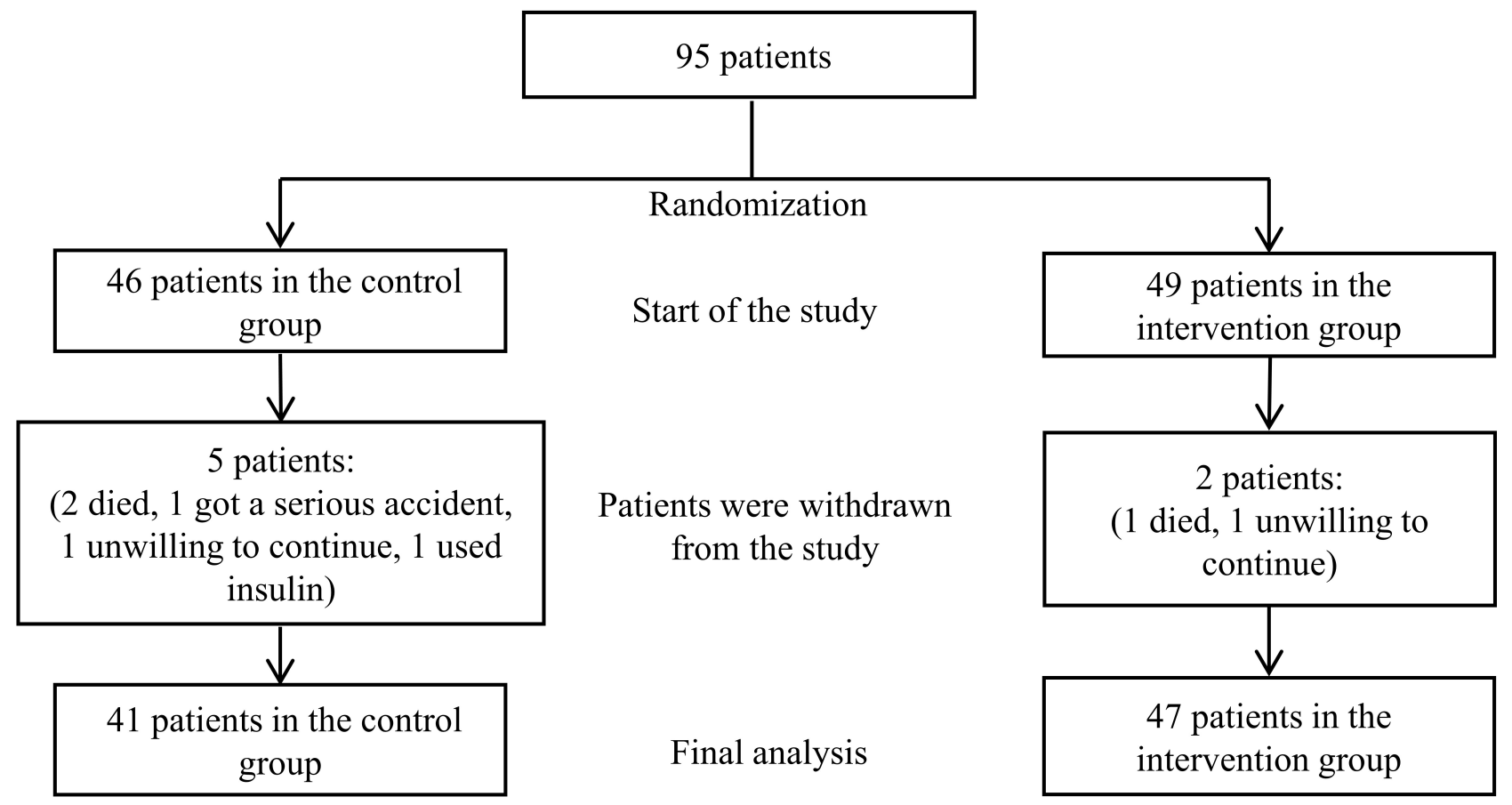

Figure 1. Flow chart of the study.

patients), got a serious accident and discontinued to participate (one patient), reluctant to continue (two patients), and switched to insulin (one patient).

Baseline demographics and clinical data are presented in Table 1. There was no significant difference in the characteristics between the groups. Female patients were dominant, accounted for about two-thirds of the patients. The mean $( \pm$ SD) age of patients was $59.12( \pm 8.39)$ years and $59.21( \pm 8.08)$ years in the control group and the intervention group, respectively. Around $40 \%$ of the patients were recently $(<5$ years) diagnosed with diabetes, with nearly $70 \%$ of them being prescribed with the combination of metformin and sulfonylureas as their oral hypoglycemia agent.

At the beginning of the study, HbAlc was not significantly different between the intervention group compared to the control group $(9.18 \% \pm 2.64 \%$ vs. $8.09 \% \pm 1.74 \%, p=0.09)$ (Table 1). A significant reduction was found in $\mathrm{HbAlc}$ of patients in the intervention arm $(-0.66 \%, p=0.004)$; meanwhile, there was a nonsignificant change in the $\mathrm{HbA} 1 \mathrm{c}$ level of the control arm $(0.24 \%, p=0.69)$. Furthermore, this study showed a significant $0.90 \%$ mean change difference between the study groups ( $p=$ 0.04) (Table 2). The percentage of patients who have reached the $\mathrm{HbA} 1 \mathrm{c}$ target of $<7 \%$ established by the American Diabetes Association increased in both groups (from $26.83 \%$ to $29.27 \%$ in the control group and from $21.28 \%$ to $29.79 \%$ in the intervention group) (Table 2).

Regarding the quality of life measurement, after 24 weeks of study, there was a significant increase in the mean change difference of DQLCTQ scores between the study groups $(4.30 \%$, $p=0.04)$. For each domain, three domains reached significant between-group improvement. The domain of "health distress" increased $6.46 \%(p=0.006)$; meanwhile, there was an increase
Table 1. Baseline characteristics of the study patients.

\begin{tabular}{lccc}
\hline & $\begin{array}{c}\text { Control } \\
(\boldsymbol{n}=\mathbf{4 1})\end{array}$ & $\begin{array}{c}\text { Intervention } \\
(\boldsymbol{n}=\mathbf{4 7})\end{array}$ & $\boldsymbol{p}$-values \\
\hline Gender & $18(43.90 \%)$ & $14(29.79 \%)$ & $0.17^{\mathrm{a}}$ \\
$\quad$ Male & $23(56.10 \%)$ & $33(70.21 \%)$ & \\
$\quad$ Female & $59.12(40-76)$ & $59.21(40-75)$ & $0.95^{\mathrm{b}}$ \\
Mean age in years (min-max) & & & \\
Mean duration of diabetes (years) & $15(35.69 \%)$ & $22(46.81 \%)$ & $0.58^{\mathrm{a}}$ \\
$<5$ & $12(29.27 \%)$ & $15(31.91 \%)$ & \\
$5-10$ & $8(19.51 \%)$ & $6(12.77 \%)$ & \\
$>10-15$ & $6(14.63 \%)$ & $4(8.51 \%)$ & \\
$>15$ & & & \\
Oral hypoglycemic agent & $8(19.51 \%)$ & $7(14.89 \%)$ & $0.52^{\mathrm{a}}$ \\
Metformin & $3(7.32 \%)$ & $5(10.64 \%)$ & \\
Sulfonilurea & $30(73.17 \%)$ & $31(65.96 \%)$ & \\
Metformin + sulfonilurea & $0(0 \%)$ & $2(4.26 \%)$ & \\
Metformin + acarbose & $0(0 \%)$ & $1(2.13 \%)$ & \\
Metformin + pioglitazone & $0(0 \%)$ & $1(2.13 \%)$ & \\
Metformin + sulfonilurea + acarbose & $8.09 \pm 1.74$ & $9.18 \pm 2.64$ & $0.09^{\mathrm{c}}$ \\
\hline HbA1c in \% (mean \pm SD) & & & \\
\hline
\end{tabular}

Chi-square.

${ }^{\mathrm{b}} t$-test.

'Mann-whitney U test.

of $6.72 \%(p=0.001)$ and $7.77 \%(p=0.01)$ on the domain of "satisfaction" and "treatment flexibility," respectively (Table 3 ).

\section{DISCUSSION}

This study is the first randomized controlled trial assessing the impact of community pharmacists in Indonesia to 
Table 2. Baseline and 24-week comparison of the HbAlc.

\begin{tabular}{|c|c|c|c|c|c|c|c|}
\hline \multirow[b]{2}{*}{ Parameter } & \multicolumn{3}{|c|}{ Control group $(n=41)$} & \multicolumn{3}{|c|}{ Intervention group $(n=47)$} & \multirow{2}{*}{$\begin{array}{c}\text { The difference in mean } \\
\text { change } \bar{X}(95 \% \mathrm{CI})\end{array}$} \\
\hline & 0 weeks $\bar{X} \pm \mathrm{SD}$ & 24 weeks $\bar{X} \pm$ SD & $\begin{array}{c}\text { Mean change } \bar{X} \\
(95 \% \mathrm{CI})\end{array}$ & 0 weeks $\bar{X} \pm$ SD & 24 weeks $v \pm S D$ & $\begin{array}{c}\text { Mean change } \bar{X} \\
(95 \% \text { CI })\end{array}$ & \\
\hline $\mathrm{HbA} 1 \mathrm{c}$ in $\%$ & $8.09 \pm 1.74$ & $8.33 \pm 2.03$ & $\begin{array}{c}0.24(-0.27-0.75) \\
p=0.69^{\mathrm{a}}\end{array}$ & $9.18 \pm 2.64$ & $8.52 \pm 2.14$ & $\begin{array}{c}-0.66(-1.12 \text { to } \\
-0.21), p=0.004^{\mathrm{a}}\end{array}$ & $\begin{array}{c}-0.90(-1.50 \text { to }-0.20) \\
p=0.04^{\mathrm{b}}\end{array}$ \\
\hline $\begin{array}{l}\text { HbAlc }<7 \% \\
\text { (\% patients) }\end{array}$ & 26.83 & 29.27 & - & 21.28 & 29.79 & - & - \\
\hline
\end{tabular}

Bold in the $p$-value indicates that the value is significant.

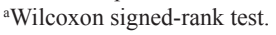

${ }^{b}$ Mann-Whitney U test. that.

Table 3. Baseline and 24-week comparison of the quality of life scores (values in percentage of total score).

\begin{tabular}{|c|c|c|c|c|c|c|c|}
\hline \multirow[b]{2}{*}{ Domain } & \multicolumn{3}{|c|}{ Control group $(n=41)$} & \multicolumn{3}{|c|}{ Intervention group $(n=47)$} & \multirow{2}{*}{$\begin{array}{c}\text { The difference in } \\
\text { mean change } \bar{X}(95 \% \\
\text { CI })\end{array}$} \\
\hline & 0 weeks $\bar{X} \pm$ SD & 24 weeks $\bar{X} \pm \mathrm{SD}$ & $\begin{array}{l}\text { Mean change } \bar{X} \\
\quad(95 \% \mathrm{CI})\end{array}$ & 0 weeks $\bar{X} \pm$ SD & 24 weeks $\bar{X} \pm \mathrm{SD}$ & $\begin{array}{l}\text { Mean change } \bar{X} \\
\quad(95 \% \mathrm{CI})\end{array}$ & \\
\hline Physical function & $80.28 \pm 20.14$ & $89.43 \pm 16.57$ & $\begin{array}{c}9.15 \text { (4.52 to } 13.77), \\
p=0.001^{\mathrm{a}}\end{array}$ & $80.17 \pm 22.09$ & $88.53 \pm 19.46$ & $\begin{array}{c}8.36(1.63 \text { to } 15.09), \\
p=0.007^{\mathrm{a}}\end{array}$ & $\begin{array}{c}-0.79(-9.06 \text { to } 7.48) \\
p=0.93^{\mathrm{b}}\end{array}$ \\
\hline Energy/fatigue & $63.90 \pm 18.19$ & $71.71 \pm 15.76$ & $\begin{array}{c}7.81(0.53 \text { to } 15.07), \\
p=0.03^{\mathrm{c}}\end{array}$ & $66.38 \pm 18.11$ & $72.77 \pm 17.35$ & $\begin{array}{c}6.38(0.09 \text { to } 12.68), \\
p=0.04^{c}\end{array}$ & $\begin{array}{c}-1.42(-10.85 \text { to } 8.01) \\
p=0.76^{\mathrm{d}}\end{array}$ \\
\hline Health distress & $89.84 \pm 11.52$ & $92.28 \pm 11.34$ & $\begin{array}{c}2.44(-1.27 \text { to } 6.15), \\
\quad p=0.28^{\mathrm{a}}\end{array}$ & $82.45 \pm 17.09$ & $91.38 \pm 12.09$ & $\begin{array}{c}8.94(5.13 \text { to } 12.75), \\
p<0.001^{\mathrm{a}}\end{array}$ & $\begin{array}{c}6.46(1.20 \text { to } 11.71), \\
p=0.006^{\mathrm{b}}\end{array}$ \\
\hline Mental health & $87.02 \pm 13.79$ & $84.59 \pm 13.34$ & $\begin{array}{c}-2.44(-8.06 \text { to } 3.19), \\
p=0.66^{\mathrm{a}}\end{array}$ & $80.43 \pm 19.17$ & $85.36 \pm 13.81$ & $\begin{array}{c}4.94(-0.28 \text { to } 10.16) \\
p=0.10^{\mathrm{a}}\end{array}$ & $\begin{array}{c}7.38(-0.19 \text { to } 14.94), \\
p=0.14^{\text {b }}\end{array}$ \\
\hline Satisfaction & $72.02 \pm 10.07$ & $70.34 \pm 4.59$ & $\begin{array}{c}-1.70(-4.63 \text { to } 1.27) \\
p=0.48^{\mathrm{a}}\end{array}$ & $66.15 \pm 9.04$ & $71.19 \pm 6.35$ & $\begin{array}{c}5.04(2.46 \text { to } 7.62), \\
p<0.001^{\mathrm{a}}\end{array}$ & $\begin{array}{c}6.72(2.90 \text { to } 10.54), \\
p=0.001^{\mathrm{b}}\end{array}$ \\
\hline $\begin{array}{l}\text { Treatment } \\
\text { satisfaction }\end{array}$ & $84.41 \pm 17.35$ & $85.88 \pm 11.63$ & $\begin{array}{c}1.47(-3.61 \text { to } 6.54), \\
p=0.81^{\mathrm{a}}\end{array}$ & $78.89 \pm 18.84$ & $86.91 \pm 16.23$ & $\begin{array}{c}7.94(1.31 \text { to } 14.56), \\
p=0.01^{\mathrm{a}}\end{array}$ & $\begin{array}{c}6.55(-1.89 \text { to } 14.98) \\
p=0.10^{\mathrm{b}}\end{array}$ \\
\hline Treatment flexibility & $54.39 \pm 13.16$ & $56.83 \pm 12.38$ & $\begin{array}{c}2.44(-2.48 \text { to } 7.36), \\
p=0.54^{\mathrm{a}}\end{array}$ & $50.55 \pm 13.72$ & $60.77 \pm 11.81$ & $\begin{array}{c}10.21(5.84 \text { to } 14.59), \\
p<0.001^{\mathrm{a}}\end{array}$ & $\begin{array}{c}7.77(1.31 \text { to } 14.24), \\
p=0.01^{\mathrm{b}}\end{array}$ \\
\hline $\begin{array}{l}\text { Frequency of } \\
\text { symptoms }\end{array}$ & $71.72 \pm 14.87$ & $78.88 \pm 16.21$ & $\begin{array}{c}7.17 \text { (2.16 to } 12.17), \\
p=0.007^{\mathrm{a}}\end{array}$ & $68.72 \pm 16.60$ & $77.00 \pm 15.35$ & $\begin{array}{c}8.28(3.93 \text { to } 12.63), \\
\quad p=0.001^{\mathrm{a}}\end{array}$ & $\begin{array}{c}1.18(-5.33 \text { to } 7.70), \\
p=0.73^{\mathrm{b}}\end{array}$ \\
\hline Total score & $75.45 \pm 9.45$ & $78.45 \pm 7.52$ & $\begin{array}{c}3.29(0.33 \text { to } 6.26), p \\
=0.03^{c}\end{array}$ & $71.64 \pm 9.96$ & $79.24 \pm 8.72$ & $\begin{array}{c}7.59(4.49 \text { to } 10.70) \\
p<0.001^{\mathrm{c}}\end{array}$ & $\begin{array}{c}4.30(0.03 \text { to } 8.57) \\
p=0.04^{\mathrm{d}}\end{array}$ \\
\hline
\end{tabular}

Bold in the $P$-value indicates that the value is significant.

${ }^{a}$ Wilcoxon signed-rank test.

${ }^{b}$ Mann-Whitney U test.

'Paired $t$-test.

${ }^{\mathrm{d} I n d e p e n d e n t ~} t$-test. $P$ that.

improve diabetes care outcomes through home visit intervention. We found that our program significantly reduced $\mathrm{HbAlc}$ and improved the quality of life of the patients.

Our $\mathrm{HbA} 1 \mathrm{c}$ reduction of $0.9 \%$ is clinically relevant based on The UK Prospective Diabetes Study (UKPDS) results (Stratton et al., 2000). Those landmark trials showed that every 1\% reduction in HbA1c over 10 years is linked with risk reductions of $21 \%$ for any diabetes-related outcomes, $21 \%$ for diabetes-related death, $14 \%$ for myocardial infarctions, and 37\% for microvascular complications (Stratton et al., 2000). Remarkably, the improvement in glycemic control observed in our study was similar to that revealed in a network meta-analysis of 43 randomized clinical trials worldwide to evaluate the effect of pharmacist based diabetes educational interventions on clinical results (Bukhsh et al., 2018). It was reported that diabetes education delivered by pharmacists plus pharmaceutical care significantly reduced $\mathrm{HbA} 1 \mathrm{c}$ level with a mean difference of $-0.86 \%$ (Bukhsh et al., 2018). Restricted to trials with 6 months of duration as ours, the glycemic control in our study is consistent with findings from Jarab et al. (2012) and Butt et al. (2016). The randomized controlled trial (RCT) from Jordan with comparable baseline HbAlc as ours showed an identical net reduction of HbAlc of $0.9 \%$ (Jarab et al., 2012). Meanwhile, another study reported a significant $\mathrm{HbA} 1 \mathrm{c}$ reduction of $1.19 \%$ in the intervention group (Butt et al., 2016). These higher changes in the HbA1c level compared to our study might be yielded due to their higher baseline HbAlc values, as patients with higher $\mathrm{HbA} 1 \mathrm{c}$ levels tend to show greater improvement in their final measurements (Machado et al., 2007; McCord, 2006). Conversely, that pattern was also confirmed by a study by Mehuys et al. (2011) as they showed a little improvement of HbA1c level $(-0.5 \%)$ from baseline $\mathrm{HbA1c}$ value of $7.7 \%$ in their intervention group. In the clinical practice context, this indicates that pharmacists should prioritize poor glycemic control patients, who may have little access with other healthcare providers and require more attention in their diabetes care.

The improvement of quality of life outcomes in our study is in agreement with the result from some previous studies. Using the Audit of Diabetes Dependent Quality of Life questionnaire, Sriram et al. (2011) found a significant improvement in the quality of life in the patients after the intervention of pharmaceutical care 
intervention in a tertiary care teaching hospital. In another study, after pharmacist intervention, there was a significant improvement in the mental component summary from SF-12 (Short Form-12) questionnaire, but the physical component summary score was not significantly altered (Johnson et al., 2008). Meanwhile, a study from Butt et al. (2016) showed a nonsignificant improvement in the total score of the EQ-5D-3L questionnaire, but there were significant increases in the dimension of "mobility" and anxiety." It is troublesome to elaborate on the quality of life result from this study with other studies due to the variety of measurement tools used across the studies.

In the Indonesian context, one of the most important solutions to advance community practice in this country is to provide firm evidence of pharmacists' contribution to healthcare (Hermansyah et al., 2018a). It is also noteworthy to say that, in the last 15 years, the Indonesian government and other pharmacist stakeholders had issued several community pharmacy policies and initiatives that indicated their enthusiasm to improve community pharmacy practice in the country (Hermansyah et al., 2018b). Among them is the updated version of the standard of pharmacy services in community pharmacy which was issued by the Indonesian Ministry of Health on the year of 2016 (Ministry of Health of Republic of Indonesia, 2016). This regulation sets minimum services delivered in pharmacy which consisted of two main roles: management of pharmaceutical and healthcare devices and provision of clinical pharmacy services. While the first role is sufficiently implemented by Indonesian pharmacists, the more patient-oriented services are still lacking establishment. A number of significant barriers, such as lack of knowledge, lack of confidence, and poor public recognition, have hindered such development (Hermansyah et al., 2016). Fortunately, based on the current study, we have demonstrated that home visits by pharmacists can improve the achievement of diabetes patients' outcomes. Likewise, from the patient perspective, our program was gladly received by the study participants and the low dropout rate in the intervention group (4.1\%) may indicate their acceptance of pharmaceutical care. Furthermore, the positive result from this study could increase pharmacist confidence in their benefit in patient care and also highlight the potential feasibility to replicate a similar activity throughout the country.

As with all studies, the findings of this study should be interpreted with caution due to its limitations. Firstly, our study might not have been representative of the general diabetes population since the patients who joined this study were managed under a special scheme, namely, "Prolanis." With this scheme, patients get their treatment under the National Health Insurance scheme in their closest public healthcare facilities. As the Indonesian government has projected the scheme that would cover all Indonesian citizens by 2019, our study is assumed to represent the most diabetes patient in Indonesia. Secondly, this study was performed for only 6 months of duration. Considering that this condition needs lifelong treatment, long-term studies are encouraged to investigate the sustainability of the observed improvements. Thirdly, this study only focused on glycemic control, but not on other condition-related diabetes outcomes such as blood pressure and lipid profile. This scenario reflected the early level of pharmaceutical care application in Indonesia when the study was conducted. However, in between completion of the study to publishing the result, community pharmacists in Indonesia have started to do simple tests like blood pressure, blood glucose, blood uric acid, and blood cholesterol in their service. Future study should utilize this development to evaluate more comprehensive outcomes. Finally, the economic outcome was not evaluated in the present study. To justify the benefit of this expanded service for the community and healthcare system, incorporating economic evaluation in a further study is urgently needed.

\section{CONCLUSION}

Community pharmacist intervention in Indonesia has positively contributed to improving glycemic control and quality of life among patients with diabetes. This result amplifies prevailing evidence from around the world regarding the benefit of pharmacist intervention on diabetes management. Also, this finding could promote an establishment of community pharmacist educational intervention in the whole country or other similar areas to manage diabetes and other chronic conditions. However, the issue of effects' sustainability and the economic outcomes of this service remain unclear and need to be evaluated in future studies.

\section{ACKNOWLEDGEMENT}

We are grateful to the patients and pharmacists in Banyumas district, Indonesia for their enthusiastic participation in this research. This study was conducted as part of Comp-Act (Community Pharmacist's Action for Chronic Disease Treatment) project.

\section{CONFLICT OF INTEREST}

None.

\section{FUNDING}

This work was funded by Indonesian Pharmacist Association-Kalbe Farma grant, Institutional Research scheme of University of Jenderal Soedirman grant, and Indonesian Pharmacist Association Central Java region grant.

\section{REFERENCES}

Agustina R, Dartanto T, Sitompul R, Susiloretni KA, Suparmi, Achadi EL, Taher A, Wirawan F, Sungkar S, Sudarmono P, Shankar AH, Thabrany H. Universal health coverage in Indonesia: concept, progress, and challenges. Lancet, 2019; 393(10166):75-102.

Ahola AJ, Groop PH. Barriers to self-management of diabetes. Diabet Med, 2013; 30(4):413-20.

Bukhsh A, Khan TM, Lee SWH, Lee LH, Chan KG, Goh BH. Efficacy of pharmacist based diabetes educational interventions on clinical outcomes of adults with type 2 diabetes mellitus: a network meta-analysis. Front Pharmacol, 2018; 10(9):339.

Butt M, Mhd Ali A, Bakry MM, Mustafa N. Impact of a pharmacist led diabetes mellitus intervention on $\mathrm{HbAlc}$, medication adherence and quality of life: a randomised controlled study. Saudi Pharm J, 2016; 24(1):40-8.

Finkelstein EA, Chay J, Bajpai S. The economic burden of self-reported and undiagnosed cardiovascular diseases and diabetes on Indonesian households. PLoS One, 2014; 9(6):e99572.

Harding JL, Pavkov ME, Magliano DJ, Shaw JE, Gregg EW. Global trends in diabetes complications: a review of current evidence. Diabetologia, 2019; 62(1):3-16.

Hartati T. Quality of life of type 2 diabetes mellitus patients; comparison between controlled and uncontrolled blood glucose (Kualitas hidup penderita diabetes melitus tipe2, perbandingan antara penderita kadar 
glukosa darah terkendali dan tidak terkendali) [Master thesis]. Universitas Gadjah Mada, Yogyakarta, Indonesia, 2003.

Hermansyah A, Pitaloka D, Sainsbury E, Krass I. Prioritising recommendations to advance community pharmacy practice. Res Social Adm Pharm, 2018a; 14(12):1147-56.

Hermansyah A, Sainsbury E, Krass I. Community pharmacy and emerging public health initiatives in developing Southeast Asian countries: a systemic review. Health Soc Care Community, 2016; 24(5):e11-22.

Hermansyah A, Sainsbury E, Krass I. Multiple policy approaches in improving community pharmacy practice: the case in Indonesia. BMC Health Serv Res, 2018b; 18(1):449.

International Diabetes Federation. Diabetes education modules. 2011. Available from: https://d-net.idf.org/en/library/178-diabetes-educationmodules-2011.html. (Accessed 20 March 2020).

Inzucchi SE, Bergenstal RM, Buse JB, Diamant M, Ferrannini E, Nauck M, Peters AL, Tsapas A, Wender R, Matthews DR. Management of hyperglycemia in type 2 diabetes: a patient-centered approach: position statement of the American Diabetes Association (ADA) and the European Association for the Study of Diabetes (EASD). Diabetes Care, 2012; 35(6):1364-79.

Jarab AS, Alqudah SG, Mukattash TL, Shattat G, Al-Qirim T. Randomized controlled trial of clinical pharmacy management of patients with type 2 diabetes in an outpatient diabetes clinic in Jordan. J Manag Care Pharm, 2012; 18(7):516-26.

Johnson CL, Nicholas A, Divine H, Perrier DG, Blumenschein K, Steinke DT. Outcomes from diabetesCARE: a pharmacist-provided diabetes management service. J Am Pharm Assoc, 2008; 48(6):722-30.

Kelly C, Rodgers PT. Implementation and evaluation of a pharmacist-managed diabetes service. J Manag Care Pharm, 2000; 6:48893.

Machado M, Bajcar J, Guzzo GC, Einarson TR. Sensitivity of patient outcomes to pharmacist interventions. Part I: systematic review and meta-analysis in diabetes management. Ann Pharmacother, 2007; 41(10):1569-82.

McCord AD. Clinical impact of a pharmacist-managed diabetes mellitus drug therapy management service. Pharmacotherapy, 2006; 26(2):248-53.

Mehuys E, Van Bortel L, De Bolle L, Van Tongelen I, Annemans L, Remon JP, Giri M. Effectiveness of a community pharmacist intervention in diabetes care: a randomized controlled trial. J Clin Pharm Ther, 2011; 36(5):602-13

Ministry of Health of Republic of Indonesia. Permenkes No. 73 tahun 2016 tentang Standar Pelayanan Kefarmasian di Apotek (Standard of pharmacy services in community pharmacy). Jakarta, Indonesia: Ministry of Health Indonesia; 2016.
Papatheodorou K, Banach M, Bekiari E, Rizzo M, Edmonds M. Complications of diabetes 2017. J Diabetes Res, 2018; 11:3086167.

Saeedi P, Petersohn I, Salpea P, Malanda B, Karuranga S, Unwin N, Colagiuri S, Guariguata L, Motala AA, Ogurtsova K, Shaw JE, Bright D, Williams R. Global and regional diabetes prevalence estimates for 2019 and projections for 2030 and 2045: results from the international diabetes federation diabetes atlas. 9th edition. Diabetes Res Clin Pract, 2019; 157:107843.

Saeedi P, Salpea P, Karuranga S, Petersohn I, Malanda B, Gregg EW, Unwin N, Wild SH, Williams R. Mortality attributable to diabetes in 20-79 years old adults, 2019 estimates: results from the International Diabetes Federation Diabetes Atlas. 9th edition. Diabetes Res Clin Pract, $2020 ; 14: 108086$

Shen W, Kotsanos JG, Huster WJ, Mathias SD, Andrejasich CM, Patrick DL. Development and validation of the diabetes quality of life clinical trial questionnaire. Med Care, 1999; 37(4 Suppl Lilly):AS45-66.

Soewondo P, Soegondo S, Suastika K, Pranoto A, Soeatmadji DW, Tjokroprawiro A. The DiabCare Asia 2008 study - Outcomes on control and complications of type 2 diabetic patients in Indonesia. Med J Indones, 2010; 19:235-44.

Sriram S, Chack LE, Ramasamy R, Ghasemi A, Ravi TK, Sabzghabaee AM. Impact of pharmaceutical care on quality of life in patients with type 2 diabetes mellitus. J Res Med Sci, 2011; 16(Suppl 1):S412-8.

Stratton IM, Adler AI, Neil HA, Matthews DR, Manley SE, Cull CA, Hadden D, Turner RC, Holman RR. Association of glycaemia with macrovascular and microvascular complications of type 2 diabetes (UKPDS 35): prospective observational study. BMJ, 2000; 321(7258):405-12.

Yaghoubi M, Mansell K, Vatanparastc H, Steeves M, Zeng W, Farag M. Effects of pharmacy-based interventions on the control and management of diabetes in adults: a systematic review and meta-analysis Can J Diabetes, 2017; 41(6):628-41.

How to cite this article:

Purwonugroho TA, Raharjo B, Maharani L, Mustikaningtias I, Utami VVFR, Galistiani GF, Baroroh HN, Pratiwi H, Samodro P, Efendi JAJ, Setiawan D. Community pharmacist home visit-based intervention improved diabetes patients' outcomes: A randomized controlled trial. J Appl Pharm Sci, 2021; 11(03):054-059. 